\title{
Adoption Analyses of Groundnut Production Technologies by Bhoochetana Beneficiaries in Hyderabad Karnataka Region
}

\author{
B. Nagesh*, S. K. Meti and G. N. Maraddi \\ ${ }^{1}$ Agricultural Research Station, Guladalli, Koppal, UAS, Raichur, Karnataka, India \\ ${ }^{2} U A S$, Raichur, Karnataka, India \\ ${ }^{3}$ AEEC, Lingasugur, UAS, Raichur, Karnataka, India \\ *Corresponding author
}

\section{Keywords}

Groundnut,

Adoption status,

Bhoochetana

programme \&

Relationship

analysis

Article Info

Accepted:

15 December 2019

Available Online:

20 January 2020
The research study was conducted on impact of training programme on knowledge, perception and attitude of stakeholders towards Bhoochetana programme. The Raichur, Koppal and Bellary districts were purposively selected based on their maximum area under groundnut cultivation. The random sampling procedure is being used to identify 180 beneficiaries. The ex-post -facto research design used for the study. It was corroborated that, 52.78 per cent of beneficiaries belonged to medium adoption category, followed by high (17.78 \%). Cent per cent of the beneficiaries fully adopted suitable variety, followed by seed rate $(84.44 \%)$ \& Seed treatment with bioagents $(63.89 \%)$. Majority $(73.89 \%)$ of the beneficiaries fully adopted recommended sowing time, followed by partial adoption $(26.11 \%)$. Exactly three fourth $(75.00 \%)$ of beneficiaries fully adopted the chemical fertilizer followed by partially adoption (19.44\%). Whereas 86.11 per cent of the beneficiaries fully adopted micro nutrients application followed by partial adoption $(11.11 \%)$. In addition to Majority $(80.56 \%)$ of the beneficiaries fully adopted the recommended time of application of chemical fertilizer and least $(5.00 \%)$ per cent of them adopted partially. It was observed that the half (52.78 $\%)$ of the beneficiaries not adopted recommended management practices for leaf minor Whereas, 45.56 per cent of them not adopted recommended management practices for red headed hairy caterpillar. With regard management of tikka disease (leaf spot), majority (55.00\%) of the beneficiaries partially adopted the recommended practices followed by no adoption $(23.33 \%)$ and full adoption $(21.67 \%)$.

\section{Introduction}

Globally, rain fed areas is hot-spots for poverty, malnutrition and degradation of natural resources. In our country, out of the total geographical area of 329 million ha, 143 million ha is under cultivation, out of which 108 million ha area is rainfed (75\%). Rainfed 
agriculture contributes about 44 per cent of the total food grain production in the country and supports 40 per cent of the population. Bulk of pulses, oil seeds, millets, coarse grains, commercial crops etc., are accounted by the rainfed agriculture. Thus, dry land holds great prospect of contributing substantially to country's food production. Unless the production from these rainfed areas increases, the real breakthrough in agriculture may not be possible. Hence, dry land development strategy is important for agriculture development in the state. Scanty rainfall on the one hand and high density of rainfall on the other are the major threats to the dry land agriculture. Improved crop production technologies with the efficient utilization of natural resources play an important role in increasing the dry land crop productivity and inturn production. Karnataka stands second in possessing area under rainfed agriculture after Rajasthan in the country. Crop yields in dry land areas are quite low (1-1.5 $\mathrm{t} \mathrm{ha}^{-1}$ ) which are lower by two to five folds of the yield from researchers managed plots. In this context, the Government of Karnataka has taken up an innovative science-led development initiative called Bhoochetana to harness the potential of rainfed agriculture in the state with the help of International Crops Research Institute for Semi - Arid Tropics (ICRISAT) which was launched on 23 May 2009.

More or less similar situation exists in Karnataka. Out of total cultivated area of 123.85 lakh ha, about 70 per cent of the area is rainfed. Major rainfed crops of the state are jawar, ragi, maize, minor millets, groundnut, sunflower, soybean, pigeonpea, greengram, bengalgram and field bean etc. It has been observed that the average yields of these crops by and large in the state are less than the national average and also averages of other states. Further, a wide gap exists in actual yield levels in the farmer's field and yields of field level demonstrations. The main responsibility of extension work lies with the Department of Agriculture. The department is striving hard to bridge the gap between the actual farmers yield and the potential yields of crops, through various extension methods. In India, the State Department of Agriculture charged with the responsibility of agricultural development has grown into mammoth service organization. The programme has completed five years. Now, it is necessary to study how the Bhoochetana programme has made an impact on knowledge level among cotton growers and relationship with their socio-engineering attributes along with management \& situational attributes. In this context, the present study is being conducted to analyse the adoption status of farm beneficiaries about the improved production technologies of Groundnut.

\section{Materials and Methods}

The study was conducted in Raichur, Koppal and Bellary districts of Hyderabad Karnataka during the year 2015-16 the districts were purposively selected because of maximum area under Groundnut is being cultivated in Hyderabad Karnataka region. The Ex-postfacto research designs were used for the study. Two talukas from each districts selected \& inturn, two villages under each talukas were selected based on the criteria of having highest area under Groundnut. Again thirty groundnut growers identified from each village. Thus total size constitutes 180 respondents. The standard \& structured schedule used for investigation, which is being tested in non sample area. The systematic random sampling procedure used to finalize Groundnut growers for the research.

Overall adoption of Bhoochetana Programme beneficiaries regarding cultivation practices of groundnut. 
The results presented in Table 1 indicated that, 52.78 per cent of respondents belonged to medium adoption category, followed by 17.78 and 29.44 per cent of the respondents belonged to high and low adoption categories, respectively. The mean adoption score of the respondents was 19.32 per cent. Considerable percentage of respondents belonged to medium level knowledge category which is corresponding with the adoption. This would influence the adoption levels of the respondent's participation and regular contact with farm facilitators might have also influenced for the above results. Knowledge influenced the level of action as it is pre requisite for decision making. Besides the knowledge, the resources available with the farmers also have bearing on the adoption level. Each farmer tends to modify certain practices to fit into his resource matrix. Therefore knowledge level coupled with resource availability could be the reasons for medium level of adoption of groundnut cultivation practices. Majority of the respondents in the present study were educated, belonged to high income category with large land holding. These must have contributed for higher adoption of groundnut cultivation practices as 27.78 per cent of them had high adoption level and 52.78 per cent had medium adoption level, together contributed for more than 70 per cent. The findings of the study were in accordance with the findings of Bhagawat (2003) and Raghavendra (2005).

Extent of adoption of Bhoochetana Programme beneficiaries regarding individual cultivation practices of groundnut

Data presented in the Table 2 indicated that, all the respondents fully adopted the improved variety of groundnut. Seed is the crucial input influencing the yield level due to this farmer put sincere efforts to ensure better crop yield. It was found that 73.89 per cent of the farmers fully adopted the practice of right sowing time and 26.11 per cent had partially adopted it. Sowing depends on labour availability and on moisture content in the field. Delayed sowing affects the yield and this prompts the framers to adopt right sowing time. It was fond that a small percentage of farmers partially adopted right sowing time due to the fact that, labour shortage during the sowing time, delayed onset of monsoon and non availability of quality seeds at the time of sowing. The findings were in line with the findings of Nagaraja (2002). Majority $(84.44 \%)$ and 15.56 per cent of the respondents fully and partially adopted the recommended seed rate respectively. It is due to farm facilitators who are facilitating regarding this seeds available at Raita Samparka Kendra.

Spacing was fully adopted by 53.89 per cent of respondents and 45.00 per cent of respondents partially adopted it. Under conditions of good plant growth such as greater fertility of the soil, availability of moisture and early sowing farmers tend to keep closer spacing than the recommended one. This could be the reason for farmers adopting varying spacing. Majority (61.67\%) of respondents applied FYM as per recommendation and 35.56 per cent partially applied which again depends on its availability with the farmer and the fertility of the soil. More than 75.00 and 19.44 per cent farmers fully and partially adopted all the chemical fertilizers practice. This could be due to inadequate knowledge among the respondents about the benefits of applying fertilizers as per the recommendation. It is evident from the table that 41.67 per cent of respondents adopted intercropping fully as it increased the yield. This is due to the fact that groundnut is one of the remunerative crop in the study area which gives higher income compared to other crops. Majority of the farmers $(75.00 \%)$ fully adopted the hand 
weeding practice while, 19.44 per cent of them fully adopted recommended herbicide. Since, more than 78.00 per cent of the farmers in the study area are small and marginal unable to purchase costly herbicides which add to the cost of cultivation.

More than half $(52.78 \%)$ of the beneficiaries fully adopted recommended management practice for leaf minor. Whereas, 55.00 per cent of them partially adopted management practices for red headed hairy caterpillar followed by full adoption (45.56 \%). With regard management of tikka disease (leaf spot), majority (57.78\%) of the beneficiaries fully adopted the recommended practices followed by partial adoption $(40.00 \%)$. Fifty per cent of the beneficiaries not adopted the recommended rust management practices followed by partial $(37.22 \%)$ and full adoption (12.78 \%). Partial adoption of recommended pest and disease management might be due to lack of knowledge regarding the practice and also complex nature involved in calculating dosage of chemical to be applied. Another reason might be that, the disease incidence occurs at the later stage of crop growth not affecting the yield levels in groundnut.

Relationship between adoptions of groundnut farm beneficiaries with their independent variables

The perusal of the Table 3 depicts that, positive and significant relationship was observed between education and adoption of recommended practices in groundnut crop. Education exposes farmers for more communication media or methods for more perception and comprehension which could be observed among better educated farmers than others. Further, an individual gathers information and relates himself to his environment. Acquisition of formal education may also help to interpret ideas in a rational manner, resulting in programmatic decision making. Thus, education provides persistent orientation to the farmers wherein they gradually learn about innovations and change on to better entrepreneur ultimately reflecting on better management of the enterprises. Therefore, the present findings seemed to be logical and this finding is in agreement with the findings of Kanavi (2000) and Rathod (2005). Farming experience of the groundnut farmers had significant relationship with adoption level of the respondents. More the farming experience better will be the understanding of recommended practices which leads to higher level of adoption. This finding is close agreement with the finding of Shinde et al., (2000).

The land holding was positively and significantly correlated with adoption of recommended practices by the groundnut growers. The probable reason for this kind of result may be that farmers with larger holdings will have more opportunities and potentialities to try and adopt large number of technological innovations. As a result, it is quite possible that farmers with larger holdings evince keen interest to know about new farm practices and be more receptive to such ideas, skills and other management factors, which intern on their extent of adoption of recommended practices. Krishnamurthy (1999) and Thippeswamy (2007) observed positive and significant relationship between size of land holdings and the adoption. Annual income of the groundnut growers was found to have positive and significant relationship with the adoption level of recommended practices. Income of farmers has influenced the adoption of recommended practices; the farmers with low annual income were low adopters while those with high annual income were high adopters. Generally, the farmers have to invest more when they have to adopt new technology or to follow scientific farm operations. This might 
be possible reason for better adoption of recommended practices by groundnut growers of high economic status. Similar findings have been reported in the past Raghavendra (1997) and Reshmy (1998).

Mass media participation was significantly related with adoption level of the respondents. This might be because of exposure to different mass media sources like newspapers, radio and television might have helped the respondents to gain recent information. Hence, farmers who had higher exposure to mass media had exhibited higher level of adoption. Similar, results were reported by Kanavi (2000) and Kharatmol (2006). The extension participation was positively and significantly related with adoption of recommended practices by farmers. The possible reason for this trend may be that, the farmers who had participated in training course, attended meeting, field days, tours, Krishimela might have come in closer contact with extension personnel and other farmers leading to increased knowledge about cultivation practices, which might have motivated them for positive action that is adoption. The other reason could be that extension participation provides opportunity for farmers to exchange their ideas based on their experience thus leading to higher adoption. The findings of the present study were in conformity with the findings reported by Kharatmol (2006). It was evident for Table 30 that, risk orientation was found to had positive and significant relationship with the adoption of recommended practices. This implies that farmers who had favorable orientation towards management and scientific knowledge would tend to be more willing to adopt the latest technology on their field and risk relates to the extent of pains taken by a farmer to achieve greater success than others. Hence risk orientation of farmers has significant effect on their adoption level of recommended practices. The findings were in line with the findings of Meti (1998) and Rathod (2005). It can be observed form the results that, achievement motivation was positively and significantly correlated with the adoption of recommended practices in groundnut at 5\% level of significance. The excellence or perfection in what one does is determining the achievement motivation and to achieve destination one need to take adequate and meticulously care to achieve success maximising and sustaining yield and income. Hence, achievement motivation was found to be significantly correlated with the adoption of recommended practices. The results are in line with the findings of Chandregowda (1996) and Resmy (1998).

Table.1 Overall adoption of Bhoochetana Programme beneficiaries regarding cultivation practices of groundnut

\begin{tabular}{|l|l|l|l|}
\hline Sl. No. & Category & Frequency & Percentage \\
\hline $\mathbf{1}$ & Low $($ mean $-0.425 * \mathrm{SD})$ & 53 & 29.44 \\
\hline $\mathbf{2}$ & Medium $($ mean $\pm 0.425 * \mathrm{SD})$ & 95 & 52.78 \\
\hline $\mathbf{3}$ & High $($ mean $+0.425 * \mathrm{SD})$ & 32 & 17.78 \\
\hline & Mean & 19.32 & \\
\hline & SD & 3.16 & \\
\hline
\end{tabular}


Table.2 Extent of adoption of Bhoochetana Programme beneficiaries regarding individual cultivation practices of groundnut

\begin{tabular}{|c|c|c|c|c|c|c|c|}
\hline \multirow{4}{*}{ Sl. No. } & \multirow{4}{*}{ Practices } & & & & & $\mathrm{n}=18$ & \\
\hline & & \multicolumn{6}{|c|}{ Extent of adoption } \\
\hline & & \multicolumn{2}{|l|}{ FA } & \multicolumn{2}{|l|}{ PA } & \multicolumn{2}{|l|}{ NA } \\
\hline & & $\mathrm{F}$ & $\%$ & $\mathrm{~F}$ & $\%$ & $\mathrm{~F}$ & $\%$ \\
\hline \multirow[t]{6}{*}{1} & \multicolumn{7}{|l|}{ Variety: Bunch type } \\
\hline & TMV-2 & 180 & 100.00 & 0 & 00.00 & 0 & 0.00 \\
\hline & JL-24 & 58 & 32.22 & 0 & 00.00 & 122 & 67.78 \\
\hline & S-206 & 55 & 30.56 & 0 & 00.00 & 125 & 69.44 \\
\hline & R-2001-03 & 42 & 23.33 & 0 & 00.00 & 138 & 76.67 \\
\hline & TGLPS-3 & 30 & 16.67 & 0 & 00.00 & 150 & 83.33 \\
\hline 2 & Seed rate: $(125 \mathrm{~kg} / \mathrm{ha})$ & 152 & 84.44 & 28 & 15.56 & 0 & 0.00 \\
\hline \multirow[t]{4}{*}{3} & \multicolumn{7}{|l|}{ Seed treatment } \\
\hline & Chemicals (per kg of seeds) ( Thiram 75 WP @3gm) & 10 & 5.56 & 55 & 30.56 & 115 & 63.89 \\
\hline & PSB: $(2.5 \mathrm{~kg} / \mathrm{ha})$ & 75 & 41.67 & 72 & 40.00 & 33 & 18.33 \\
\hline & Rhizobium: $2.5 \mathrm{~kg} / \mathrm{ha}$ & 102 & 56.67 & 45 & 25.00 & 33 & 18.33 \\
\hline 4 & Sowing time: (june-july) & 133 & 73.89 & 47 & 26.11 & 0 & 0 \\
\hline 5 & Spacing: $(30 * 10 \mathrm{~cm})$ & 97 & 53.89 & 81 & 45.00 & 2 & 1.11 \\
\hline 6 & FYM (ha): 7.5 tonnes /ha & 111 & 61.67 & 64 & 35.56 & 5 & 2.78 \\
\hline 7 & Vermicompost : 1 ton /ha & 98 & 54.44 & 10 & 5.56 & 72 & 40.00 \\
\hline \multirow[t]{3}{*}{8} & \multicolumn{7}{|l|}{ Chemical fertilizer: } \\
\hline & Macro nutrients (N:P:K) 25:50:25 /ha & 135 & 75.00 & 35 & 19.44 & 10 & 5.56 \\
\hline & Micronutrients: $\left(\mathrm{ZnSO}_{4}\right.$, Gypsum- $25 \mathrm{~kg}, 500 \mathrm{~kg} / \mathrm{ha}$ & 155 & 86.11 & 20 & 11.11 & 5 & 2.78 \\
\hline 9 & $\begin{array}{l}\text { Time of application of chemical fertilizer: } \\
\text { (100\% Basal dose) }\end{array}$ & 145 & 80.56 & 9 & 5.00 & 26 & 14.44 \\
\hline 10 & Intercultivation: $15,30,40$ DAS & 115 & 63.89 & 37 & 20.56 & 28 & 15.56 \\
\hline \multirow[t]{3}{*}{11} & \multicolumn{7}{|l|}{ Weed management } \\
\hline & Hand weeding: one time & 135 & 75.00 & 40 & 22.22 & 5 & 2.78 \\
\hline & $\begin{array}{l}\text { Herbicide application (Pre emergence): } \\
\text { Alachlor 50 EC @3 lit /ha }\end{array}$ & 35 & 19.44 & 111 & 61.67 & 34 & 18.89 \\
\hline \multirow[t]{3}{*}{12} & \multicolumn{6}{|l|}{ Insect pests management: } & \\
\hline & $\begin{array}{l}\text { a) Leaf minor : @ 2ml Profenophos or } 2 \mathrm{gm} \\
\text { thiomethaxam } 75 \mathrm{WP} / \text { lit }\end{array}$ & 31 & 17.22 & 43 & 23.89 & 106 & 58.89 \\
\hline & b) Red headed hairy caterpillar & 34 & 18.88 & 64 & 35.56 & 82 & 45.56 \\
\hline \multirow[t]{3}{*}{13} & \multicolumn{7}{|l|}{ Diseases management: } \\
\hline & $\begin{array}{l}\text { a) Leaf spot @ Carbondizum } 0.05 \% \text { or } \\
\text { Hexoconozole } 0.2 \% \text { or Difonoconozole } 0.1 \%\end{array}$ & 23 & 12.78 & 67 & 37.22 & 90 & 50.00 \\
\hline & b) Tikka disease & 39 & 21.67 & 99 & 55.00 & 42 & 23.33 \\
\hline \multirow[t]{2}{*}{14} & \multicolumn{7}{|l|}{ Intercropping: } \\
\hline & Groundnut + Redgram (11:1) & 75 & 41.67 & 16 & 8.89 & 89 & 49.44 \\
\hline
\end{tabular}

FA-Full Adoption, PA-Partial Adoption, NA-No adoption

F- Frequency $\%$ - Percentage 
Table.3 Relationship between adoption of groundnut farm beneficiaries with their independent variables

\begin{tabular}{|c|c|c|}
\hline Sl. No. & Characteristics & Correlation coefficient (r) \\
\hline 1 & Age & 0.087 \\
\hline 2 & Education & $0.157 *$ \\
\hline 3 & Farming experiences & $0.336 * *$ \\
\hline 4 & Land holding & 0.007 \\
\hline 5 & Annual income & $0.324 * *$ \\
\hline 6 & Material possession & 0.122 \\
\hline 7 & Livestock possession & -0.103 \\
\hline 8 & Cropping intensity & 0.048 \\
\hline 9 & Extension participation & $0.364 * *$ \\
\hline 10 & Extension contact & -0.081 \\
\hline 11 & Social participation & 0.037 \\
\hline 12 & Mass media participation & -0.052 \\
\hline 13 & Cosmopoliteness & $0.248 * *$ \\
\hline 14 & Innovativeness & 0.041 \\
\hline 15 & Risk orientation & $0.157 *$ \\
\hline 16 & Achievement motivation & $0.302 * *$ \\
\hline 17 & Economic motivation & $0.430 * *$ \\
\hline 18 & Management orientation & $0.270 * *$ \\
\hline
\end{tabular}

$\mathrm{n}=180$

It is concluded that increase in adoption status among the beneficiaries is being observed due to exposure in various capacities building programme conducted under Bhoochetana programme. It was concluded that improvement in the adoption status of beneficiaries on production technologies like suitability of Groundnut genotype, spacing, water management, and pest \& disease management is noticed. Hence this improvement of adoption status is being influenced by various independent variables of beneficiaries. As result, increase in marginal return by reducing cost of cultivation, which is due to timely adoption of suitable technologies enchased for higher marginal return in groundnut enterprise.

\section{References}

Bhagwat, M. R. and Gohad, V. V., 2003, Adoption of dryland cotton cultivation technology by the farmers. Maharashtra J. Extn. Edu., 22(2): 108-110. 
Chandregowda, M. J. and Jayaramaiah, M., 1996, Integrated nutrient management in rice farming under four rice ecosystems. Organic Farming and Sustainable Agriculture Abstracts, National Seminar, October 9-11 organized by Univ. of Agric. Sci., Bangalore.

Kanavi, V. P., 2000, A study on the knowledge and adoption behaviour of sugarcane growers in Belgaum district of Karnataka. M. Sc. (Agri.) Thesis, Univ. Agric. Sci., Dharwad (India).

Kharatmol, 2006, Impact of trainings conducted on vermicompost by Krishi Vigyan Kendra, Bijapur. M Sc. (Agri.) Thesis, Uni.Agric.Sci. Dharwad Karnataka (India).

Krishanamurthy, B., 1999, An analysis of impact of the farmers field on IPM in rice. Ph.D Thesis, Univ. Agric. Sci., Bangalore.

Meti, S. K., 1998, Technology reach, perception, knowledge, adoption and attitude towards improved agricultural technologies by small and marginal farmers in Tungabhadra command area. Ph. D. Thesis, Univ. Agric. Sci., Dharwad (India).

Nagaraja, M. V., 2002, A study on knowledge of improved cultivation practices of sugarcane and their extent of adoption by farmers in Bhadra command area in Davanagere district, Karnataka state. Ph. D. Thesis, Univ. Agric. Sci.,
Dharwad. Karnataka (India).

Raghavendra, R., 2005, Knowledge and adoption of recommended cultivation practises of Cauliflower in Belgaum of Karnataka. M. Sc (Agri.) Thesis, Univ. Agric. Sci., Dharwad, Karnataka (India).

Raghavendra, H. N., 1997, A study on knowledge and adoption behaviour of arecanut farmers of South Canara district, Karnataka state. M. Sc. (Agri.) Thesis, Univ. Agric. Sci., Bangalore, Karnataka (India).

Rathod Devaraj Naik, 2005, A study on knowledge and adoption pattern improved sugarcane practices in sugarcane. M. Sc. (Agri) Thesis, Univ. Agric. Sci., Dharwad.

Reshmy, C., 1998, A study on sustainability of coconut and banana intercropping in kerala-An analysis. M. Sc. (Agri.) Thesis, Univ. Agric. Sci., Bangalore, Karnataka (India).

Shinde, P. S., Vaidya, V. R. and Satpute, S. K., 2000, Identification and adoption of indigenous agricultural practices by dryland farmers. Maharashtra J. Extn. Edun., $19: 259-263$.

Thippeswamy, R., 2007, A study on knowledge and adoption of plant protection measures in coconut cultivation by farmers of Chitradurga district. M.Sc. (Agri.) Thesis, Univ. Agric. Sci., Dharwad, Karnataka (India).

\section{How to cite this article:}

Nagesh, B., S. K. Meti and Maraddi, G. N. 2020. Adoption Analyses of Groundnut Production Technologies by Bhoochetana Beneficiaries in Hyderabad Karnataka Region. Int.J.Curr.Microbiol.App.Sci. 9(01): 1974-1981. doi: https://doi.org/10.20546/ijcmas.2020.901.223 